\title{
Doop, sending en die opkoms van die juridiese kerkbegrip
}

PJ VAN DER MERWE

Dit is vry algemeen bekend dat enige denke of opvatting oor die doop saamhang met die wyse waarop daar oor die kerk gedink word. Teen die agtergrond van ons breë tema, "Doop en verbond", wil ek vervolgens hierdie samehang aan die orde stel, met spesifieke verwysing na die vroeë Middeleeuse kerk- en sendinggeskiedenis en die juridiese kerkbegrip wat in dié tyd na vore getree het.

Ironies genoeg word die vroeë wortels van die juridiese kerkbegrip onder andere na Augustinus teruggevoer. Ironies, omdat hierdie kerkvader bekend staan vir die geestelike of "organiese" wyse waarop hy oor die kerk gedink het. Weijland sê byvoorbeeld van hom: "Tegenover een krampachtig zich vastklemmen aan de laatste resten van een ecclesia sine ruga et macula, die altans in de persoon van de ambtsdragers bewaar moest blijven om de gave van de Geest en daarmee het heil te garanderen, stelde Augustinus zijn grootse conceptie van de kerk als de liefdeband in de Geest, die door een gelovig verbonden-zijn aan Christus in de communio sanctorum zijn meest wezenlijke gestalte en in de broederband van alle katholieke christenen op aarde zijn ondeelbare eenheid vond" (Weijland 1965:9). Aan die ander kant het hy hom weer daaraan skuldig gemaak dat hy nie voldoende onderskeid getref het tussen die kerk op aarde en die mistieke corpus Christi nie, en dat hy gevolglik te veel reg en aanspraak aan die kerklike instituut toegeken het (Weijland 1965: 187). So stel hy byvoorbeeld die heilsnoodsaaklikheid van lidmaatskap aan die ecclesia catholica teenoor die aansprake van die Donatiste in Noord-Afrika. Na Augustinus word ook die spreuk Roma locuta res finita est teruggevoer. Hierdie "institusionele" denkwyse kan goed verklaar word uit Augustinus se lang stryd met ketterse groepe, maar dit neem ook nie weg dat hy daarmee die deur vir die juridiese denke wyd oopgemaak het nie.

Dit sou selfs moontlik wees om hierdie tweeslagtigheid in sy denke in Romeinse regsterme uit te druk: Die kerk is societas, 'n lewende gemeenskap van gelowiges wat hulle vrywillig by mekaar skaar vanweë hulle gesamentlike geloof in Jesus Christus. Die kerk is egter ook universitas, 'n liggaam met regspersoonlikheid wat homself in die 
wêreld kan laat geld, 'n liggaam met verpligtinge en regte wat homself ook teenoor die ander groot korporatiewe persoonlikheid, die staat, kan laat geld.

Naas die denke van teoloë groei die juridiese kerkbegrip ook uit die "kanonieke" denke. Die ius canonicum is 'n vorm van kerkreg wat gewoonlik van die Protestantse kerkreg onderskei word. Dit groei in die vroeë kerk aan die hand van die Romeinse regsdenke. Namate die kerk hom al meer in die Romeinse wêreld gevestig en tuisgemaak het, moes hy hom ook met betrekking tot die Romeinse reg aanpas. Die Romeinse regstelsel was immers die weefsel wat die makro-gemeenskap van die ryk aanmekaar gehou het. Die inheemswording van die kerk het hom verplig om homself ook teenoor hierdie stuk werklikheid aan te pas.

Kahl (1978: 41) wys verder op die invloed wat die Theodosiese sakrale reg op die kanonieke denke uitgeoefen het. Hierdie sakrale reg het vir die grootste deel teruggegaan op die oud-Romeinse sakrale reg. In Konstantinopel het die kerk gewoon in die vakuum in beweeg wat deur die vergange heidense staatskultus gelaat is. In die Weste is die Romeinse regsbegrippe weer aangewend om die kerklike selfstandigheid teenoor die staat uit te bou. Gregorius die Grote het 'n belangrike rol gespeel in die versterking van die kanonieke reg, en daarmee saam in die opkoms van die juridiese kerkbegrip.

Van betekenis is die feit dat die kanonieke regspleging apart van die kerklike pastoraat verloop het. Calvyn identifiseer later hierdie verwikkeling as een van die belangrikste wendings wat die kerk tot die verwording van Rome gelei het. Die kanonieke reg ontwikkel ook apart van die hoofstroom van die teologie en word in sy ontwikkeling swaar deur Romeinse regsbronne beïnvloed.

Hierdie gang van sake word voorts deur die sosio-politieke omwentelinge van die vroeë Middeleeue aangehelp. Die Romeinse owerheidstruktuur en regstelsel stort in duie en kerklike ampsdraers word toenemend die kundiges waarna mense vir hulle alledaagse vrae en sake omsien. Kerklike regsgeleerdes moet al meer ook in sekulêre aangeleenthede uitspraak gee. Kloosterbiblioteke bly oor as van die laaste bewaarplekke van die Romeinse regsbronne. Die ineengestrengelheid van sekulêre en kanonieke reg is die gevolg. Dit is ook een van die beste voorbeelde van hoe die Corpus Christianum daar uitgesien het.

Dit verbaas nie dat die juridiese kerkbegrip in hierdie omstandighede die vernaamste denkmodel geword het wanneer daar oor kerk gedink is nie. Wanneer Roomse teoloë in die tydperk na die Reformasie 
vir die eerste keer daartoe kom om 'n leer van die kerk te formuleer, is dit in erg juridiese terme. Bellarminus (1628), die leidende teoloog in die Kontra-reformatoriese periode vir sover dit die leer van die kerk aangaan, bedien homself van feitlik uitsluitlike juridiese argumente om die alleenaanspraak van die kerk van Rome om kerk te wees, te betoog. Hy gaan selfs so ver om die onderskeid tussen die liggaam en siel van die kerk wat tot op daardie stadium nog gehandhaaf is, te laat vaar. Sy beskrywing van die kerk van Rome is klassiek en welbekend: "Die kerk is ' $n$ vergadering van mense wat net so sigbaar en tasbaar is as die vergaderde volk van Rome, die koninkryk van Frankryk of die Republiek Venesië." Die juridiese kerkbegrip word tot 'n hoogtepunt gevoer in die ensikliek Mystici corporis (1943) wanneer pous Pius XII die kerk as 'n societas hierarchica beskryf met bepaalde historiese en juridiese gronde in sy aanspraak om alleen kerk te wees (teenoor byvoorbeeld die Reformasie) (Berkhof 1967: 95).

Vervolgens kyk ons na die doop teen hierdie geskilderde agtergrond, veral soos dit in die sendingkonteks gefunksioneer het.

Reeds vroeg in die Middeleeue kom die gedagte na vore van die character indelibilis van die doop. Volgens dié gedagte bring die doop wesenlik ' $n$ verandering in statu et habitu by die gedoopte mee (Kahl 1978: 50). Op sy beurt het hierdie gedagte weer hand aan hand gegaan met 'n kultiese verstaan van die sakramente (Kahl 1978: 51). Wie dus ook al gedoop is, is aan hierdie werking van die doop onderworpe, ja selfs hulle wat hulle doop verwerp. Wie eenmaal gedoop is, kan dit nie ongedaan maak nie en verkeer lewenslank onder die aanspraak wat die doop meebring. Eweneens kan hulle hul ook nie aan die verpligtinge ontworstel wat hulle doop meebring nie. Gedooptes verkeer lewenslank onder die aanspraak van die kerk en daar is niks wat hulle daaraan kan doen nie.

Die doop is by uitstek gesien as daardie handeling waardeur "'n mens lidmaat van die kerk word". Selfs Augustinus wat swaar klem op die persoonlike geloofsbeslissing en die vrywillige confessio fidei gelê het as voorwaardes waaraan volwassenes moet voldoen om tot die doop toegelaat te word, sien een van die vernaamste effekte van die handeling daarin dat die persoon ingelyf word in die heilsgemeenskap van Jesus Christus met sy gelowiges. Omdat die kinders vir hom net so veel deel van die geloofsgemeenskap is as die volwassenes, moet hulle ook gedoop word, al is hulle nog nie tot 'n eksplisiete geloof in staat nie. Christus het immers gewaarsku dat die kindertjies nie van Hom 
geweer moet word nie. Wie ook al die doop van die kindertjies weerhou, weerhou hulle van die kerk en sluit daarmee ook die hemel vir hulle toe. Wanneer die doop later kulties verstaan word, word hierdie redenasie omgedraai om te beteken dat wie ook al gedoop is, is onomkeerbaar lidmaat van die kerk. Die doop word dan 'n kulties-institusionele handeling waardeur mense lede word van die kerklike instituut, met al die gepaardgaande verpligtinge.

Lê ons nou verder ook die verband na die juridiese kerkbegrip, sien ons dat die doop ' $n$ regshandeling word met verregaande implikasies. Dit is dan ook een van die primêre wyses waarop daar tydens die Middeleeue oor die doop gedink is. Enersyds beteken die doop dat 'n persoon lewenslank homself bind aan die kerk en dat hy ook alle gepaardgaande verpligtinge aanvaar. Andersyds stel die doop die kerklike instituut in staat om met betrekking tot die gedooptes in werking te tree, veral ten opsigte van opsig en tug. Die kerklike societas word dus met die doop gebou. Laastens word die doop ook uitgemaak as die grens tussen daardie twee belangrike arbeidsvelde van die kerk, te wete sending en pastoraat (Kahl 1978: 49, 50, 53, 54).

Dit moet egter ook op hierdie stadium gesê word dat Augustinus teen enige vorm van dwangmatige doop gekant was. Hy het byvoorbeeld die reg van individue erken om te weier om die doop te ontvang, omdat nie alle mense tot die geloof geroep word nie. Hy was ook sterk gekant teen die kultiese verstaan van die doop, soos dit na vore gekom het in die stryd met die Donatiste. Hy het as voorwaarde vir die bediening van die doop aan volwassenes 'n uitgebreide katechumenaat vereis.

In die verdere verloop van kerk- en sendinggeskiedenis sien ons dat belangrike verskuiwings binne hierdie breë raamwerk plaasvind. Eerstens het daar 'n afwatering van die katechumenaat plaasgevind. Gregorius die Grote het byvoorbeeld voorgestel dat daar aangepas sal word by die gees en bevatlikheid van die mense onder wie sending gedoen word. Ons bemerk ' $n$ neiging om die etiese aansprake van die geloof as kategese-onderwerp uit te stel tot na die doop, sodat baie gedooptes eers na hulle doop behoorlik agtergekom het waarvoor hulle hul ingelaat het (Kahl 1978: 48, 49).

Tweedens vervaag die eksplisiete geloof geleidelik as voorwaarde vir die volwasse doop en kom in die plek daarvan die sogenaamde "implisiete geloof" - 'n eenvoudige, goedgelowige aanvaarding van wat die kerk simboliseer. Dit gebeur veral na die tyd van Gregorius.

Derdens kom die verskynsel na vore dat daar in die sending al vroeër 
gedoop word, omdat daar geredeneer word dat dit makliker is om die heidene met die kerklike tug reg te skaaf as om hulle voor die tyd met die sendingprediking reg te preek. So word die probleme van die sending gewoon na die pastoraat aangegee. ' $n$ Belangrike aspek van die pastoraat word gevolglik die "ontpaganisering" van die lidmate van die kerk. Die ware geloof word 'n vae ideaal wat dalk in die komende geslagte bereik kan word (Kahl 1978: 52).

So gebeur dit dan dat die betekenis van die doop geleidelik verander. Dit word onder andere duidelik uit die semantiese gebruik van terme soos fidelis, infidelis, apostasis en perfidia. Fidelis word die ekwivalent van "iemand wat trou is teenoor God en die kerk", "iemand wat trou is teenoor die Christelike orde", "'n vertroubare lid van die samelewing". Daarenteen beteken infidelis "iemand buite die Christelike orde", "'n landsgevaarlike". Die grens tussen hierdie twee groepe is die doop. Die doop vervlak dus tot ' $n$ belangrike burgerlike formaliteit. Die ergste vorm van perfidia is apostasis. Dit is wat gebeur wanneer mense wat eenmaal gedoop is, hulle rug op hulle doop, op die kerk en die Christelike samelewing draai. Selfs Augustinus was ten gunste daarvan dat sulke mense of groepe hardhandig behandel word en dat hulle desnoods met geweld in die kraal teruggebring moes word. Hiervoor sou die kerk hom, volgens Augustinus, selfs op die owerheid kon beroep. Later ontwikkel hieruit die sogenaamde bellum iustum-gedagte - die gedagte van die heilige oorlog, aanvanklik eers teen "apostaatsgebiede" en later ook teen die halstarrige heidene (Kahl 1978: 45, 53).

Dit verbaas dan nie dat daar toenemende druk op die ongedooptes toegepas is nie. Aanvanklik was dit subtiel, byvoorbeeld deur hulle met die verskrikkinge van die hel te teister of verhoogde belastings te laat betaal. Later word dit minder subtiel. Kahl meen dat die dwangdooppraktyk soos onder andere deur Karel die Grote toegepas, minder algemeen voorgekom het as wat soms geglo word. Die Vierde Konsilie van Toledo (633) het ook eksplisiet hierdie praktyk afgewys. Dat dit egter voorgekom het, kan nie ontken word nie.

So sien ons dan hoe die doop aan die hand van 'n juridies-institusionele kerkbegrip verword het tot 'n burgerlike regshandeling waardeur die individu deel word van die Corpus Christianum. Die doop wat die inlywing van die gelowiges in die liggaam van Christus en die afwassing van sondes moes be-teken en verseël, het 'n wye poort geword waardeur die heidendom die kerk binnegestroom het. Dit het die bose sirkel versterk, sodat die kerk al verder van sy oorspronklike roeping weggeraak het. 


\section{Literatuurverwysings}

BERKHOF, H 1967. De kerk, in Berkhof, H 1967. Protestantse verkenningen na Vaticanum II. 'S-Gravenhage: Boekencentrum.

DIETZFELBINGER, W 1962. Die Grenzen der Kirche nach römischkatholischer Lehre. Göttingen: Vandenhoeck.

KAHL, HD 1978. Die ersten Jahrhunderte des missionsgeschichtlichen Mittelalters. Bausteine für eine Phänomenologie bis ca. 1050, in Schäferdiek, K (Hrsg) 1978. Die Kirche des früheren Mittelalters (Kirchengeschichte als Missionsgeschichte Band II). München: Kaiser.

SIMONIS, W 1968. Heilsnotwendigkeit der Kirche und Erbsünde bei Augustinus, in Andresen, C (Hrsg) 1981. Zum Augustin-Gespräch der Gegenwart III. Darmstadt: Wissenschaftliche Buchgesellschaft.

WEIJLAND, HB 1965. Augustinus en de kerkelijke tucht. Kampen: Kok. 